\title{
INVESTIGATION THE PROBLEMS OF DEVELOPMENT THE PROTECTION SYSTEM OF INTELLECTUAL PROPERTY AND THEIR INFLUENCE ON INNOVATIVE ACTIVITY IN AGRO-INDUSTRIAL ENTERPRISES OF UKRAINE
}

\author{
O. S. TIUSHKEVYCH, PhD student \\ Uman National University of Horticulture
}

У статті розглянуто теоретичні та практичні засади управління інновачійною діяльністю агропромислових підприємств України. Досліджено сутність інновацій, інноваційної діяльності та політики. Визначено види ефекту та результати від інноваиійної діяльності підприємств. Проаналізовано проблеми, щзо ї̈ стримують. Вказано перешкоди на шляху інновачійного розвитку аграрного сектору України. Проаналізовано проблем розвитку системи охорони інтелектуальної власності Розглянуто пріоритетні напрями інноваційного розвитку агропромислових підприємств. Запропоновано дієві заходи щэодо підвищення ефективності інноваційної діяльності аграрних підприємств.

Ключові слова: інновачія, інноваційна діяльність, система охорони інтелектуальної власності ресурсозберігаючі технологї̈, науково-технічний прогрес, модернізачія, ефективність.

Formulation of the problem. With the development of market relations, the urgency of defining new approaches in the management of scientific and technological progress, which provides innovative development of enterprises. Innovation policy in a broad sense combines science, technology, entrepreneurship, economics and management, it affects the entire socio-economic environment, including industry, banks, scientists, the level of scientific and technical education of the population. Today there is no doubt that the development of innovation policy is one of the most important functions of the state.

Analysis of recent research and publications. A significant contribution to the study of the peculiarities of innovation, innovation policy and innovation was made by foreign scientists B. Santo, B. Twis, A.B. Titov, J.A. Schumpetert and others. Among ukrainian scientists: G.O. Androschuk, Yu.M. Bazhal, Yu.V. Kindzersky, P.P. Mykytyuk, I.A. Shovkun, L.I. Fedulova and others. However, it should be noted that in the scientific literature there are still insufficiently developed issues related to the management of innovation and innovative development of enterprises in market conditions.

Research methodology. The theoretical and methodological basis of the study were the works of national and foreign scientists, leading scientists and practitioners in the field of innovation. In the process of writing general theoretical methods were 
used. The system method was used in the study of theoretical aspects of innovative technologies. The method of analysis is used to characterize the receipt of applications for inventions in Ukraine. With the help of abstract-logical substantiated and presented conclusions and proposals for the development of effective mechanisms for implementing the strategy of innovative development of Ukraine's economy.

The purpose of the article is to study the features of innovation activities of agro-industrial enterprises and to develop approaches to effective implementation of innovations in their activities.

Research results. In the Law of Ukraine "On Investment Activity" innovation activity is considered as one of the forms of investment activity carried out in order to implement the achievements of scientific and technological progress in production and the social sphere, which includes: technologies;

release and distribution of fundamentally new types of equipment and

- $\quad$ progressive intersectoral structural changes;

- $\quad$ implementation of long-term scientific and technical programs with long payback periods;

- funding of basic research for the implementation of qualitative changes in the state of productive forces;

development and implementation of new, resource-saving technology designed to improve the social and environmental condition [1].

However, today there are some of problems that hinder the innovative activity of national agro-industrial enterprises. The main ones are:

- inconsistency of the system of coordination and management of agroindustrial complex in market conditions (detachment of research institutions from market needs, development of obsolete technologies "on the shelf", individual actions of institutes and agricultural enterprises);

- inconsistency of state and other economic forms and mechanisms of management of innovation processes;

- insufficient number or absence of financial institutions, imperfect legal framework that regulates and stimulates the activities of innovative enterprises;

- outdated material and technical base of research institutions;

- insufficient awareness of scientists, lack of opportunity to visit the best companies in Ukraine and the world to share experiences;

- lack of specialists in the field of innovation management [2].

The word "innovation" is an abbreviated expression of the words "investment in innovation". The Latin word innovatio — «restoration, improvement», is based on English innovation $[3 ; 4 ; 5]$.

In our opinion, innovations are historical changes in all phases of reproduction, covering the means and objects of labor, technology and forms of organization of production. They are represented both in the field of research and development, and in the functioning of the entire process of reproduction, its management. 
Innovation covers the entire process of creating, disseminating and using a specific scientific and technical solution. It serves to meet both new and existing societal needs at a higher level. Therefore, innovation is often defined as the result of combining the capabilities of scientific and technological solutions with the economic and social needs of society.

Innovation policy is a complex and not always risk-free process, the course of which is determined by many preconditions: technical, financial, economic and social. At the same time, it is obvious that a certain part of new projects will inevitably be unrealized directly at enterprises. At the same time, in all developed countries of the world attempts are made to create a clear policy capable of responding to rapid and unexpected changes in the situation, to support complex projects with a high degree of technical and financial risk for enterprises $[6 ; 7 ; 8]$.

Depending on the results and costs taken into account, distinguish the following types of effect from the implementation of innovative activities.

Table 1. Types of effect from innovative activity of enterprises

\begin{tabular}{|l|l|}
\hline \multicolumn{1}{|c|}{ Kind of effect } & \multicolumn{1}{|c|}{ Factors, indicators } \\
\hline 1. Economic & $\begin{array}{l}\text { The indicators take into account in value terms all types of results } \\
\text { and costs that are due to the implementation of innovations. }\end{array}$ \\
\hline $\begin{array}{l}\text { 2. Scientific and } \\
\text { technical }\end{array}$ & Novelty, simplicity, utility, aesthetics, compactness. \\
\hline 3. Financial & $\begin{array}{l}\text { The calculation of indicators is based on financial indicators. } \\
\text { 4. Resource } \\
\text { and consumption of a particular type of resource. }\end{array}$ \\
\hline 5. Social & $\begin{array}{l}\text { The indicators take into account the social results of the } \\
\text { implementation of innovations. }\end{array}$ \\
\hline 6. Ecological & $\begin{array}{l}\text { Noise, electromagnetic field, illumination (visual comfort), } \\
\text { vibration. The indicators take into account the impact of } \\
\text { innovation on the environment. }\end{array}$ \\
\hline
\end{tabular}

Source: Complied by the author using [4-5]

The results of innovative activity of enterprises are expressed in innovative products, which can be in the form of material form or without it (for example, "know-how") and are subject to legal protection [6, p. 213]. Material results of innovative activity are in the form of created and mastered new machines, equipment, devices, devices and means of automation. From the point of view of production, new products can be divided into new (original), modernized, modified, improved, individual execution, mastered by production abroad and at the enterprises of Ukraine, repaired, from production waste, reuse.

In general, the result of innovation is to increase the competitiveness of manufactured products, its successful implementation in domestic and foreign markets. Currently, the most pressing problem of increasing the competitiveness of the economy and high-quality economic growth is the creation and implementation of a systematic approach to the protection and management of intellectual property in 
Ukraine to make fuller use of national intellectual results and scientific and technological progress.

We believe that although in recent years in Ukraine enough attention has been paid to the problems of development of the intellectual property protection system and its regulatory support, but the implementation of the main provisions of these regulations is inadequate. As evidenced by the dynamics of applications for inventions, so in 2019 they were received 3852 against 4495 in 2015, respectively (Table 2, Fig. 1).

Table 2. Receipt of applications for inventions in Ukraine

\begin{tabular}{|l|c|c|c|c|c|}
\hline \multicolumn{1}{|c|}{ Indexes } & 2015 & 2016 & 2017 & 2018 & 2019 \\
\hline Total applications & 4495 & 4093 & 4047 & 3968 & 3852 \\
\hline National procedure & 2506 & 2422 & 2495 & 2355 & 2298 \\
\hline National applicants & 2271 & 2230 & 2282 & 2105 & 2096 \\
\hline Legal entities & 1127 & 1206 & 1201 & 1163 & 1180 \\
\hline Foreign applicants & 235 & 192 & 213 & 250 & 202 \\
\hline PCT procedure & 1989 & 1671 & 1552 & 1613 & 1554 \\
\hline Including national applicants & 2 & 1 & 4 & 2 & 1 \\
\hline
\end{tabular}

Source: Complied by the author using [11-13]

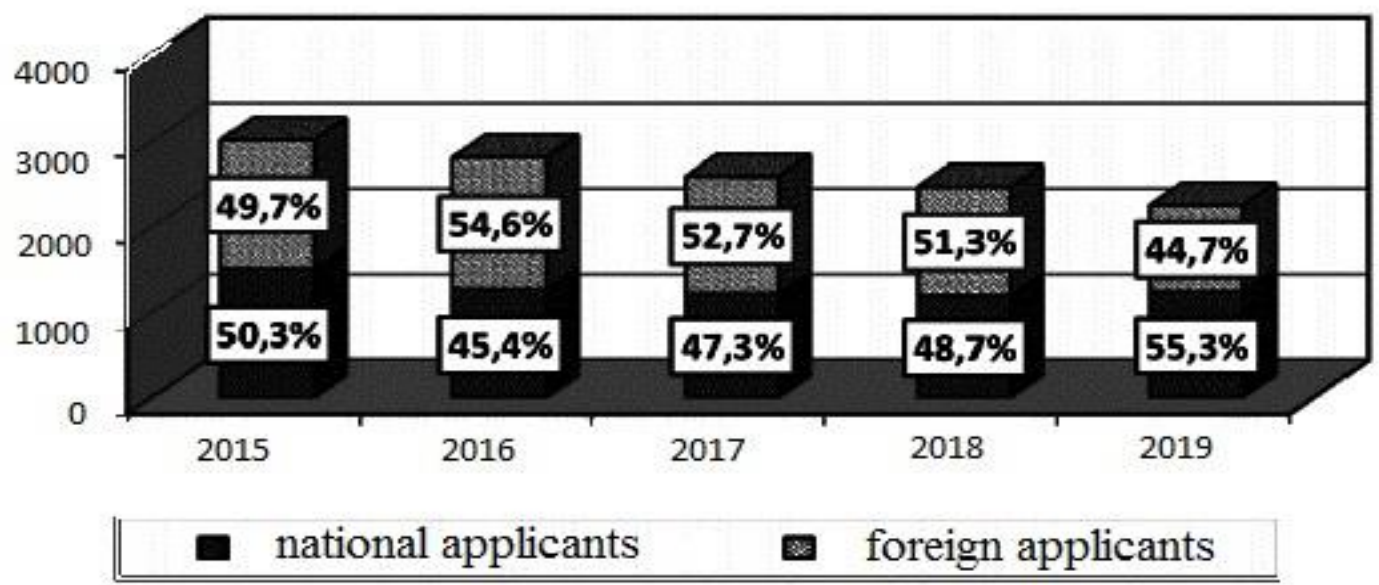

Fig. 1. Dynamics of the structure of applications for inventions Source: Complied by the author using [11-13]

The number of applications from national applicants did not change during the period under review, and the number of applications from foreign applicants decreased by $5.7 \%$, which indicates the latter's distrust of the economic and political situation in Ukraine. Critical assessments of the situation in the field of protection of intellectual property of Ukraine, in particular objects of industrial property rights, are confirmed by data from international and national official sources [11-13].

In Ukraine, organizations involved in the assessment of intellectual property 
are members of the following all-Ukrainian public organizations: All-Ukrainian Association of Appraisers (AFO), Ukrainian Society of Appraisers (UTO), Federation of Business and Intellectual Property Appraisers (FOBIV).

In 2019, national applicants submitted 2,097 applications for inventions (over $54 \%$ of the total number). The largest number of applications came from applicants from Kyiv (34.5 \%), Kharkiv (16.5\%), Dnipropetrovsk (9.2 \%), Odessa (6.9 \%), Lviv (4.5\%), Donetsk ( $3.5 \%)$, Kyiv (3.0 \%) and Vinnytsia $(2.4 \%)$ oblasts. The distribution of applications by regions of Ukraine in 2019 is shown in Fig. 2 [9, p. $7-$ 9]. The largest number of applications was submitted in Kyiv region, and the least in Volyn region (4 - $0.2 \%$ ) and Chernivtsi region (4 - $0.2 \%$ ), which indicates the shortcomings of the regional distribution of finances, which has consequences for the development of science.

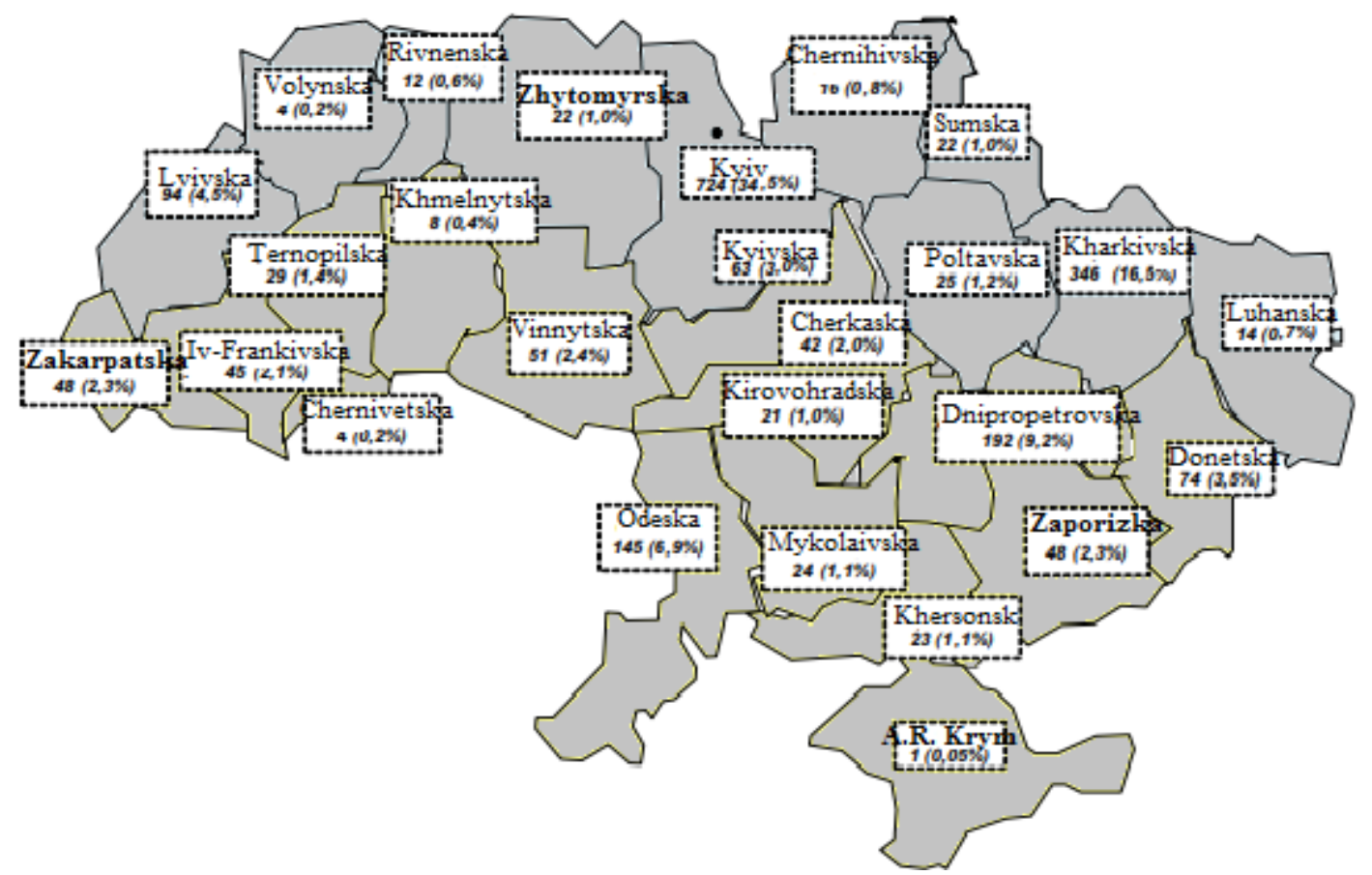

Fig. 2. Distribution of applications by regions of Ukraine in 2019 Source: Complied by the author using [11-13]

According to the Intellectual Property Office, in recent years the number of international patent applications filed under the Patent Cooperation Treaty (PCT) has consistently exceeded 110,000 . The patenting process is particularly significant in Japan, the United States and European countries. For example, if it took Japan 95 years to register the first million patents, the second million took only 15 years. PCT and companies from developing countries, especially China, Brazil and the Republic of Korea, are increasingly used [10].

Due to the unresolved issues of commercialization and introduction of economic results of intellectual activity, taking into account the optimal combination of interests of their authors, business and the state, intangible assets in Ukraine do not exceed $1.5 \%$ of fixed assets, which is much lower than the average in EU countries. equal to $50-80 \%$ of the book value of enterprises and organizations. 
We also consider it appropriate to note that neither the State Department of Intellectual Property nor the State Statistics Committee of Ukraine take into account the number of applications for international registration under WIPO procedures, which makes it impossible to compare Ukraine's place in global trademark, utility and other registration processes. intellectual property rights.

These data show that the existing system of intellectual property management is inefficient and does not meet modern priorities of technological development and requirements for economic growth.

Taking into account the socio-economic features of today, we offer some of the priority organizational and economic measures to develop effective mechanisms to strengthen the role of intellectual property in the implementation of the strategy of innovative development of Ukraine's economy. In particular, it is necessary:

1. Ensure valuation and acceptance on the balance sheet of enterprises and organizations in the form of intangible assets of intellectual property rights, other results of scientific and scientific-technical activities, created at public expense and intended for use. This is extremely important for scientific and technical enterprises and those that need to be privatized.

2. To promote the gradual creation of a national network of commercialization and transfer of technologies and innovations based on the organization of regional centers. This will improve the infrastructure of interaction between the market and research organizations, promote access of business structures and industrial enterprises to the latest technologies, increase the effectiveness of science, stimulate executives and project managers to solve problems of their market use at an early stage.

3. Take into account that given the weak demand of industry for scientific and technical achievements and small volumes of research conducted at public expense, a promising form of promotion of intellectual property in economic circulation may be the development of programs and incentives for scientific and technological partnership between government agencies. academic, sectoral and educational sectors of science and industry. It is also advisable to develop a legal framework for the possibility of establishing a scientific and technological cluster by state organizations and private enterprises.

4. Reduce by $80-75 \%$ the current rates of fees for patenting inventions and utility models. The current financial and economic crisis may stimulate the process of waiving Ukrainian state-owned enterprises and research organizations from intellectual property rights and transferring the flow of intellectual property to individuals for whom benefits are set to pay fees.

5. Develop and implement mechanisms of state support for patenting inventions abroad, created in accordance with the priorities of technological development of the country. This will contribute to the legal protection of exports of science-intensive and innovative products and reduce its risks.

6. To provide the state statistical supervision over introduction of innovations in Ukraine and the world, taking into account the used objects of intellectual property and their patent purity. This will allow annually monitoring the 
situation regarding the effectiveness of cooperation between creators of intellectual developments, enterprises and organizations, as well as determine the level of influence of scientific and technological actors on productivity and competitiveness of products and services and make adequate government decisions. It is also necessary to use the experience of OECD countries and introduce annual scientific and statistical accounting of production, exports and imports of products according to the level of knowledge intensity of industries.

7. Develop a procedure for determining remuneration, royalties, lump sum payments to authors for the use of property rights to intellectual property rights created at public expense. Unresolved issues and lack of remuneration traditions lead to payments to inventors in enterprises of insignificant amounts during the first two years or complete absence of payment, which results in disinterest of inventors and authors in the use of intellectual property rights, inhibition of inventive activity [10].

Conclusions. The purpose of innovation policy of the world's leading countries is to promote the development of science and technology; increasing innovation activity, which ensures the competitiveness of national products on the world market, the country's defense capabilities; improves the environmental situation, as well as promotes the development of long-term venture business. Therefore, the state should stimulate innovation and develop the main areas of support for enterprises working on the implementation of state innovation programs.

The proposed recommendations for developing effective mechanisms to strengthen the role of intellectual property in implementing the strategy of innovative development of Ukraine's economy should be adapted to the guidelines of modern economic policy of Ukraine in order to accelerate the restructuring of national policy based on innovative development model and knowledge economy.

\section{Література:}

1. Про інвестиційну діяльність: Закон України від 18.09.1991 № 1560XII зі змінами і доповненнями. Відомості Верховної Ради України. 2005. № 47. C. 646-657.

2. Височан О.С. Наукові підходи до визначення понять "Інновації" та "Інноваційна діяльність у сільському господарстві. Вісник Хмельницького начіонального університету. 2011. № 2. С. 101-104.

3. Про інноваційну діяльність: Закон України від 04.07.2002 №40-IV зі змінами і доповненнями. Відомості Верховної Ради Украӥни. 2002. № 36. С. 34-40.

4. Інноваційний розвиток економіки: модель, система управління, державна політика: навч. посіб. За ред.Л. І. Федулової. Київ: Основа. 2005. $552 \mathrm{c}$.

5. Інноваційно-технологічний розвиток України: стан, проблеми, стратегічні перспективи: Аналітичні матеріали до Парламентських слухань «Стратегія інновачійного розвитку України на 2010-2020 роки в умовах глобалізаиійних викликів». Федулова Л.І., Бажал Ю.М., Шовкун І.А. та ін./ за ред. Л. І. Федулової, Г.О. Андрощука. К. Ін-т економіки та прогнозування НАН України, 2009. 196 с. 
6. Микитюк П.П. Інноваційний менеджмент. Тернопіль: Економічна думка, 2006. 295 с.

7. Новий курс: реформи в Україні. 2010-2015. Національна доповідь. В. М. Гейця та ін. Київ :НВЦ НБУВ. 2010. 232 с.

8. Кіндзерський Ю.В., Якубовський М. М., Галиця І. О. та ін. Потенціал національної промисловості: цілі та механізми ефективного розвитку. За ред. канд. екон. наук Ю. В. Кіндзерського. Київ: НАН України. 2009. $928 \mathrm{c}$.

9. Відділ охорони інтелектуальної власності. URL: http://www.nbuv.gov.ua/node/2781

10. Департамент інтелектуальної власності України. URL: https://www.me.gov.ua/Documents/Detail?title=DepartamentRozvitkuTorgivli

11. Державний комітет статистики України. URL: http://www.ukrstat.gov.ua/imf/meta/dks.htm

12. Річний звіт 2019. "Український інститут інтелектуальної власності". Київ:Укрпатент. 2020. 69 c. URL: https://ukrpatent.org/atachs/zvit-ukr-2019.pdf

13. Сальник О.М. Використання досвіду функціонування технологічних парків країн-членів СС в Україні:Актуальні проблеми економіки. 2009. № 10. С. 20-28.

14. Федулова Л. І. Інноваційна економіка. Київ: Либідь. 2006. 478 с.

\section{References:}

1. On investment activity: Law of Ukraine of 18.09.1991 № 1560-XII with changes and additions. Information of the Verkhovna Rada of Ukraine. 2005. no 47. pp 646-657 (in Ukrainian).

2. Vusochan, O.S. (2011). Scientific approaches to the definition of the concepts "Innovation" and "Innovative activity in agriculture. Bulletin of Khmelnytsky National University, no 2, pp. 101-104 (in Ukrainian).

3. On innovative activity: Law of Ukraine of 04.07.2002 №40-IV with changes and additions. Information of the Verkhovna Rada of Ukraine, no 36. pp. 3440 (in Ukrainian).

4. Innovative economic development: model, management system, public policy: textbook. method / edited by Fedulova L.I. Kyiv: Basis. 2005. 552 p. (in Ukrainian).

5. Innovative-technological development of Ukraine: state, problems, strategic perspectives: Analytical materials for the Parliamentary hearings "Strategy of innovative development of Ukraine for 2010-2020 in the context of globalization challenges". Fedulova L.I., Bazhal Yu. M., Shovkun I. A. and others / ed. Fedulova L.I, Androschuk G.O. Kyiv: Institute of Economics and Forecasting of the National Academy of Sciences of Ukraine, 2009. 196 p. (in Ukrainian).

6. Mykytyuk, P.P. ( 2006.) Innovation Management. Ternopil: Economic Thought, 295 p. (in Ukrainian).

7. New course: reforms in Ukraine. 2010-2015. National report. Heitz V.M and others. Kyiv: NVC NBUV, 2010. p. 232 (in Ukrainian). 
8. Kindzersky, Y.V., Yakubovsky, M.M., Galicia, I.O. et al. (2009). The potential of national industry: goals and mechanisms for effective development. Kyiv: National Academy of Sciences of Ukraine, 928 p. (in Ukrainian).

9. Department of Intellectual Property Protection. Retrieved from: http://www.nbuv.gov.ua/node/2781 (in Ukrainian).

10. Department of Intellectual Property of Ukraine. Retrieved from: https://www.me.gov.ua/Documents/Detail?title=DepartamentRozvitkuTorgivli (in Ukrainian).

11. State Statistics Committee of Ukraine. Retrieved from: http://www.ukrstat.gov.ua/imf/meta/dks.htm (in Ukrainian).

12. Annual Report 2019: "Ukrainian Institute of Intellectual Property ".Kyiv: Ukrpatent. 2020. 69 p. Retrieved from: https://ukrpatent.org/atachs/zvit-ukr2019.pdf (in Ukrainian).

13. Salnyk, O.M. (2009). The use of experience in the operation of technology parks of EU member states in Ukraine: Current economic problems, no 10, pp. 20-28 (in Ukrainian).

14. Fedulova, L.I. (2006). Innovative economy. Kyiv: Lybid, 478 p. (in Ukrainian).

\section{Аннотация}

\section{Тюикевич E.C.}

Исследование проблем развития системь органов интеллектуальной собственности и их влияния на инновационную деятельность агропромышленных предприятий Украины

Цель статьи заключается в исследовании проблем развития системь охраны интеллектуальной собственности, их влияния на инновационную деятельность агропромышленных предприятий Украины и разработке подходов эффективного внедрения инноваций в их деятельность.

В прочессе написания использовались общетеоретические методы. При исследовании теоретических аспектов инновационных технологий использован системный метод. При характеристике поступления заявок на изобретения в Украине использовано метод анализа. С помощью абстрактно-логического обоснованно и изложены выводы и предложения по разработке эффективных механизмов реализации стратегии инновационного развития экономики Украины.

В настоящее время актуальной проблемой повымения конкурентоспособности экономики и качественного экономического роста является создание и реализачии системного подхода в защите и управлении интеллектуальной собственностью в Украине для более полного использования национальных результатов интеллектуальной деятельности и достижений научно-технического прогресса. Мы считаем, что хотя в Украине в последние годы уделяется достаточно внимания проблемам развития системы охраны интеллектуальной собственности и ее нормативно-правового обеспечения, однако реализация основных положений указанных нормативно-правовых актов является ненадлежащей. О чем свидетельствует динамика поступлений заявок на изобретения, так в 2019 году. Их поступило 3852 против 4495 в 2015 
соответственно. Количество заявок за исследованный период от национальных заявителей практически не менялась, а от иностранных заявителей - уменьшилась на 5,7\%, что указывает о недоверии последних к экономической и политической ситуации в Украине.

Критичность оценок ситуации в отечественной сфере охраны интеллектуальной собственности, в частности объектов права промышленной собственности, подтверждается данными межсународных $u$ национальных официиальных источников.

Приведенные в статье данные свидетельствуют, что существующая система управления интеллектуальной собственностью является неэффективной и не отвечает современным приоритетам технологического развития и требованиям к экономическому росту.

С учетом социильно-экономических особенностей настоящего нами предложено первоочередные организачиионо-экономические меры по разработке эффективных механизмов усиления роли интеллектуальной собственности в реализации стратегии инновационного развития экономики Украиныл. В частности, необходимо: 1. Способствовать поэтапном созданию наџиональной сети коммерцฺиализаџии и трансфера технологий и инноваций на основе организации региональных цуентров. 2. Разрабатывать программы $и$ стимуль научно-технологического партнерства между государственными структурами в академическом, отраслевом и образовательном секторах науки и промышленности. Целесообразно также разработать правовую базу для возможности основания государственныли организациями и частными предприятиями научно-технологического кластера. 3. Снизить на 80-75\% действуюшие ставки сборов за патентование изобретений $u$ полезных моделей. 4. Разработать и внедрить механизмы государственной поддержки патентования изобретений за границей, созданных в соответствии $c$ приоритетами технологического развития страны и др.

Предложенные рекомендацчии по разработке эффективных механизмов усиления роли интеллектуальной собственности в реализации стратегии инновачионного развития экономики Украины должны быть адаптированными к ориентиров современной экономической политики страны с изелью ускорения темпов структурной перестройки национальной политики на основе инновационной модели развития и экономики знаний.

Ключевые слова: иновация, инновачуионная деятельность, система охраны интелектуальной собственности, ресурсосберегающие технологии, научно-технический прогресс, модернизачия, ефективность

\section{Annotation}

\section{Tyushkevich O.S.}

Investigation the problems of development the protection system of intellectual property and their influence on innovative activity in agro-industrial enterprises of Ukraine

With the development of market relations, the urgency of defining new approaches in the management of scientific and technological progress, which provides innovative development of enterprises.

The purpose of the article is to study the problems of development of the intellectual property protection system, their impact on the innovation activities of 
agricultural enterprises of Ukraine and to develop approaches to effective implementation of innovations in their activities.

In the process of writing general theoretical methods were used. The system method was used in the study of theoretical aspects of innovative technologies. The method of analysis is used to characterize the receipt of applications for inventions in Ukraine. With the help of abstract-logical substantiated and presented conclusions and proposals for the development of effective mechanisms for implementing the strategy of innovative development of Ukraine's economy.

Currently, the most pressing problem of increasing the competitiveness of the economy and high-quality economic growth is the creation and implementation of a systematic approach to the protection and management of intellectual property in Ukraine to make fuller use of national intellectual results and scientific and technological progress.

We believe that although in recent years in Ukraine enough attention has been paid to the problems of development of the intellectual property protection system and its regulatory support, but the implementation of the main provisions of these regulations is inadequate. As evidenced by the dynamics of applications for inventions, so in 2019 they received 3852 against 4495 in 2015, respectively. The number of applications from national applicants during the period under review did not change, and from foreign applicants - decreased by $5.7 \%$, which in indicates the distrust of the latter to the economic and political situation in Ukraine. Critical assessments of the situation in the domestic sphere of intellectual property protection, in particular objects of industrial property rights, are confirmed by data from international and national official sources.

The data presented in the article show that the existing system of intellectual property management is inefficient and does not meet modern priorities of technological development and requirements for economic growth.

Taking into account the socio-economic features of today, we have proposed priority organizational and economic measures to develop effective mechanisms to strengthen the role of intellectual property in the implementation of the strategy of innovative development of Ukraine's economy. In particular we need: 1. To promote the gradual creation of a national network of commercialization and transfer of technologies and innovations based on the organization of regional centers. 2. To develop programs and incentives for scientific and technological partnership between government agencies in the academic, sectoral and educational sectors of science and industry. It is also advisable to develop a legal framework for the possibility of establishing a scientific and technological cluster by state organizations and private enterprises. 3. Reduce by 80-75\% the current rates of fees for patenting inventions and utility models. 4. Develop and implement mechanisms of state support for patenting inventions abroad, created in accordance with the priorities of technological development of the country, etc.

The proposed recommendations for developing effective mechanisms to strengthen the role of intellectual property in implementing the strategy of innovative development of Ukraine's economy should be adapted to the guidelines of modern economic policy in order to accelerate the restructuring of national policy based on innovative development model and economical knowledges.

Key words: innovation, innovative activity, system of protection of intellectual property, resource-saving technologies, scientific and technical progress, modernization, efficiency 